\title{
光触媒消臭繊維「セルフクリア $\left.{ }^{\circledR}\right\rfloor$
}

Photocatalytic Deodorant Fiber "SELF CLEAR ${ }^{\circledR}$ ",

渡辺義 弘

\section{1.はじめに}

臭気に関連する繊維としては、抗菌・防臭繊維、消臭繊 維がある。抗菌・防臭繊維は人体の皮虐常在菌の増殖を抑 制することによって常在菌による汗中の尿素からのアンモ ニアの発生を防止する、つまり、臭気の発生を抑えるもの である。一方、消臭繊維は臭気成分を吸着などによって除 去する脱臭作用も含め、分解、酸化などの化学的作用ある いは物理的作用で臭気を除去又は緩和するものと考えら

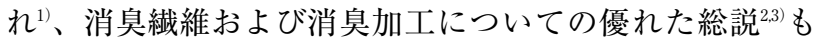
いくつか示されている。また、消臭性能の評価方法 ${ }^{4}$ も文 献に見られる。

木村らによると、消臭の手段は以下の 4 つに分類される （表 1)。すなわち、(1)感覚的消臭、(2)物理的消臭、(3) 生物的消臭、(4)化学的消臭、である。また、瀻維の消臭 加工方法は、(1)繊維の原綿段階で消臭機能を付与する方 法(消臭材料の練り込みなど) と、(2)糸、生地などに後加 工する方法、の 2 つに大別され、各種加工方法については 特許マップ゚)として詳細にまとめられ ている。

このように消臭繊維については既に 多くの文献があり、実際の製品も数多 く市販されているが、ここでは物理的 および化学的消臭を応用して原綿段階 で消臭機能を付与した光触媒消臭瀻維

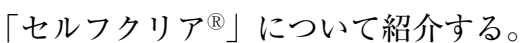

\section{2. 光触媒機構と「セルフクリア ${ }^{\circledR} 」$ の繊維構造}

光触媒反応は、太陽光などのエネル ギーを吸収してスーパーオキサイドア ニオン $\left(\cdot \mathrm{O}^{2-}\right)$ とヒドロキシラジカル $(\cdot \mathrm{OH})$ を生成し、これらが各種悪臭

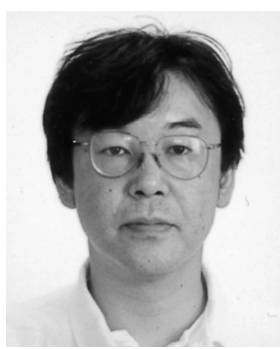

YOSHIHIRO WATANABE

日本エクスラン工業株式会社 研究所 主席研究員

T704-8510 岡山市金岡東町 3-3-1

Tel :086-942-9830 Fax:086-942-9855

E-mail :watanabe@exlan.co.jp

〈専門〉機能繊維の開発
表 1 消臭機構の種類

\begin{tabular}{|c|c|}
\hline 感覚的消臭 & $\begin{array}{l}\text { 強い芳香により不快臭を感じなくさせる。 } \\
\text { 植物抽出成分が使われるが多い。 }\end{array}$ \\
\hline 物理的消臭 & $\begin{array}{l}\text { 活性炭、ゼオライトなど吸着剤が持つ細孔 } \\
\text { に黒臭分子を閉じ込める。飽和に達すると } \\
\text { 逆に高濃度の悪臭分子が出てきてしまうこ } \\
\text { とがある。 }\end{array}$ \\
\hline 生物的消臭 & $\begin{array}{l}\text { 微生物の代謝作用によって悪臭を分離する } \\
\text { 繊維に応用した例はない。 }\end{array}$ \\
\hline 化学的消臭 & 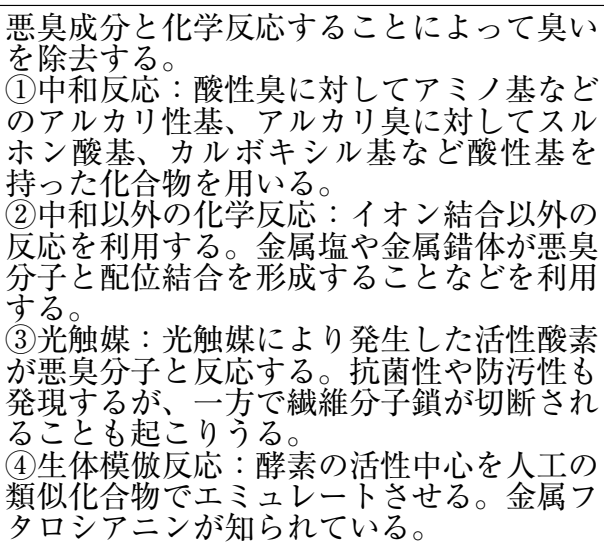 \\
\hline & $\begin{array}{l}\text { こ吸収されると、そのエネルギー } \\
\text { 上正孔(h+)が出来る }\end{array}$ \\
\hline & 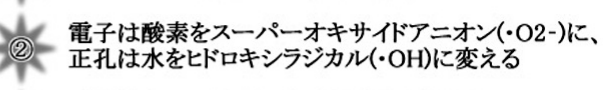 \\
\hline & 祭する \\
\hline
\end{tabular}

@゚: 悪臭や細菌、污れ

図 1 光触媒反応機構

成分、細菌などに作用して分解する作用であり(図 1)、こ の機能を有する材料としては酸化于タンなどが知られてい る)。光触媒機能を利用した消臭瀻維は既に酸化チタンを 中心とする材料を各種繊維に付与したものが各社から市販 されている。

最近になって、アクリル瀻維に特殊な酸化チタン系材料 を纎維内部に付与した光触媒消臭繊維「セルフクリア ${ }^{\circledR} 」$ 


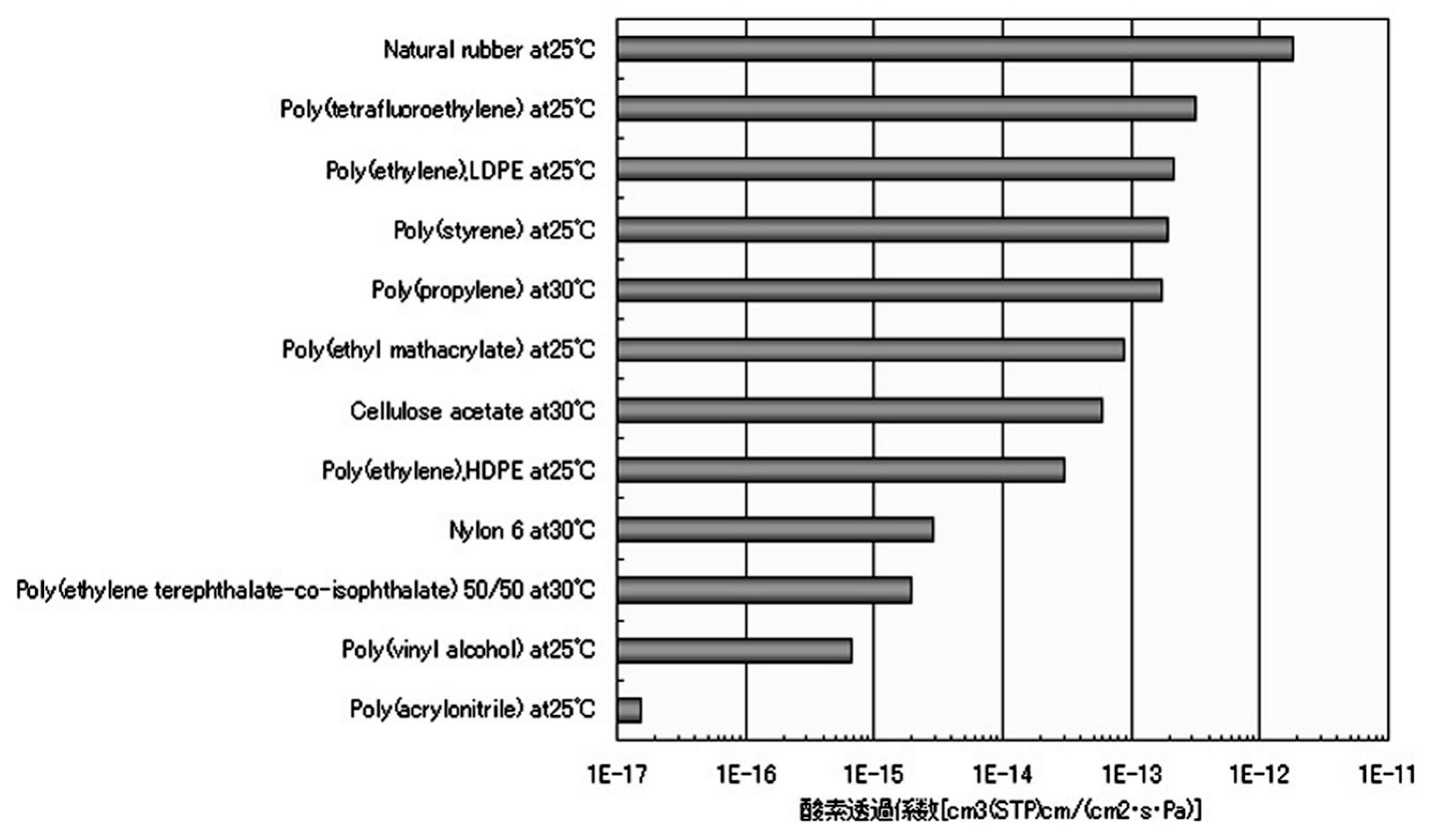

図 2 各種繊維の酸素透過係数

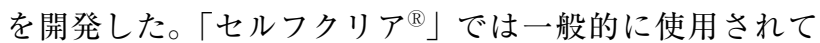
いる酸化チタンに比べ $1 / 10$ 以下の粒子径である平均 15 $\mathrm{nm}$ の超微粒子光触媒酸化チタンを含有させている。原理 的には更に粒子径の小さい超微粒子光触媒酸化チタンを含 有させることが出来ればより消臭性能は良好となるが、実 際には繊維中での超微粒子光触媒酸化チタンの二次凝集が 生産における大きな課題となるためこのレベルに止めてい る。

アクリル繊維は一般的にガスバリア性7)に優れており (図 2)、光触媒酸化チタンをアクリル䋊維中に含有させた だけではその光触媒反応を充分に利用することは出来ない。

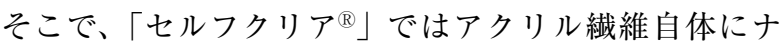
ノサイズの表面連通細孔構造(図 3) を導入、通常のアクリ

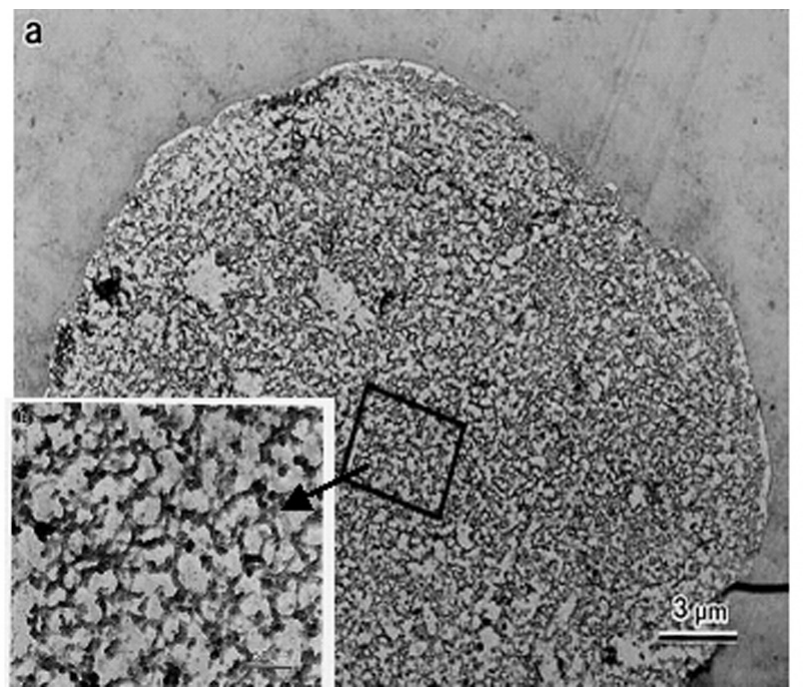

図３「多孔性アクリル繊維」の断面構造
ル繊維の 10 倍 (約 $30 \mathrm{~m}^{2} / \mathrm{g}$ ) 近い細孔表面積、すなわち、物 理吸着面積を持たせている。尚、アクリル繊維への細孔導 入は技術的には表面積として $100 \mathrm{~m}^{2} / \mathrm{g}$ も可能であるが、 紡績、染色などの繊維加工性からこのレベルに止めている。

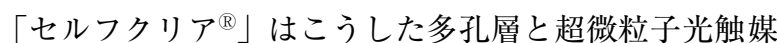
酸化チタンを含有させた緻密層を交互に配列した多層構造 を採用している(図 4)。臭気成分は先ず繊維の細孔内に物 理吸着され、そこに存在する超微粒子光触媒酸化チタンに よって分解される。この多孔構造と超微粒子光触媒酸化于

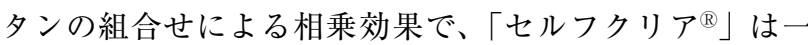
般の光触媒材料による消臭繊維に比べ著しく高い消臭効果 を示す。

また、光触媒材料から発生するラジカルは繊維の基材そ のものや後加工の場合のバインダーに対しても影響を及ぼ すため、繊維強度の低下や材料の脱落といった機能劣化を 引き起こすが、各種繊維の中でも最も良好な耐候性(図 5)

\section{光触鄓消臭の消臭-デテル圆}

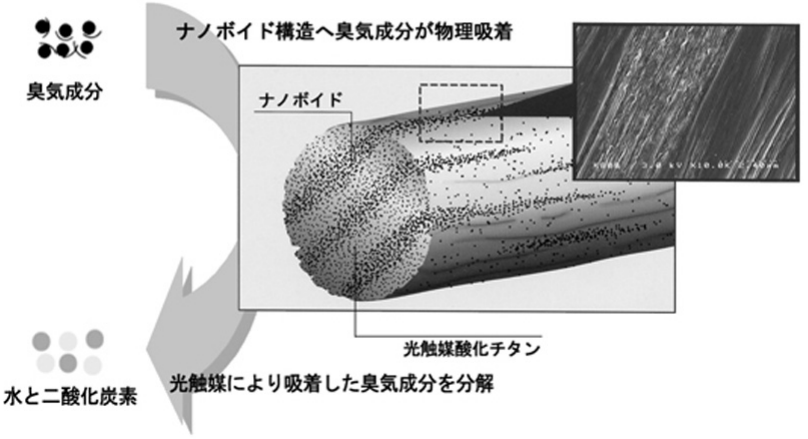

図 4 「ルフクリア ${ }^{\circledR} 」$ 消臭の仕組み 

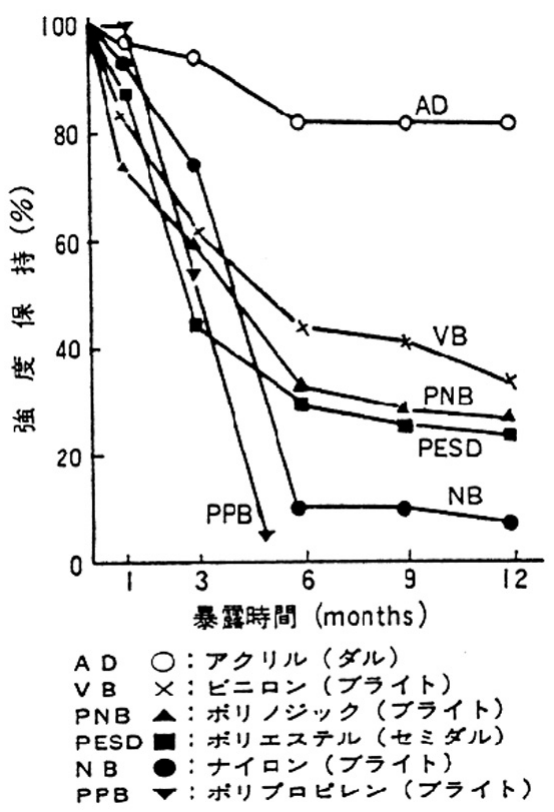

図 5 各種繊維の耐候堅牢性

を持つアクリル繊維 8 を基材として用いることにより、「セ ルフクリア ${ }^{\circledR} 」 は$ 優れた機能安定性を有している。

\section{3.「セルフクリア ${ }^{\circledR} 」 の$ 消臭性能}

\section{1 消臭性能の試験方法}

$1 \mathrm{~g}$ の試料を $3 \mathrm{~L}$ テドラーバッグに入れて密封し、その中 に所定濃度の臭気成分を $1.5 \mathrm{~L}$ 注入し、紫外線強度 $0.25 \mathrm{~mW} / \mathrm{cm}^{2}$ の光を所定時間照射し、その時のテドラー バッグ内の臭気成分濃度をガス検知管で測定した。

\section{2 臭気成分の吸放出挙動}

$\left\lceil セ ル フ ク リ ア{ }^{\circledR} 」 と\right.$ 汎用アクリル繊維、羊毛、木綿に ついて臭気成分ホルムアルデヒドを用い、その吸放出挙動 を評価した。具体的には紫外線照射下において吸着挙動を 評価した後、テドラーバッグ内を脱気、フレッシュエアを 充填した後、紫外線非照射下で雾囲気温度を上昇させ放出 挙動を評価した。その結果、汎用アクリル繊維、羊毛、木 綿については䨌囲気温度の上昇により臭気成分の放出が認

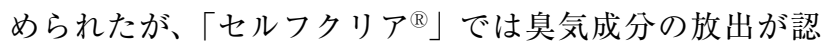
められず、光触媒反応により臭気成分が分解されているこ とが分かる(図 6)。
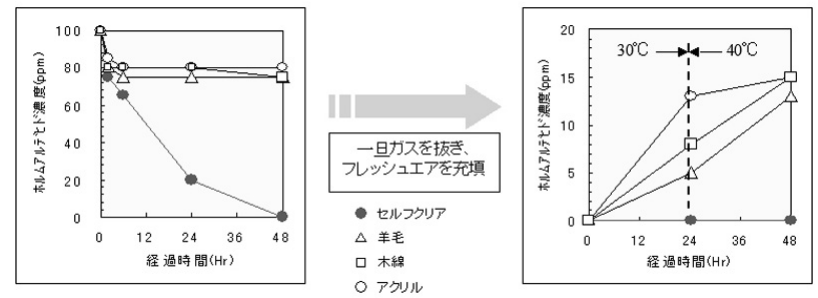



\section{3 臭気成分の分解挙動}

更に「セルフクリア $\left.\left.{ }^{\circledR}\right\rfloor と 「 セ ル フ ク リ ア{ }^{\circledR}\right\rfloor て ゙$ 用いる
超微粒子光触媒酸化チタンについて臭気成分アセトアルデ ヒドを用い、臭気成分の分解挙動を評価した。具体的には 紫外線照射下においてアセトアルデヒド、及びその分解物 として発生する二酸化炭素の濃度を評価した。その結果、 アセトアルデヒド濃度が低下するとともに二酸化炭素濃度

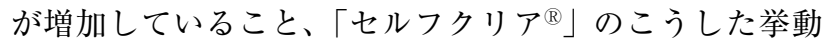
が「セルフクリア ${ }^{\circledR} 」 て ゙$ 用いる超微粒子光触媒酸化チタン

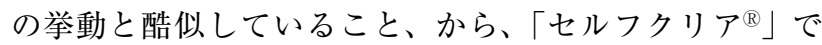
は光触媒反応を有効に利用出来ていることが分かる(図 7)。
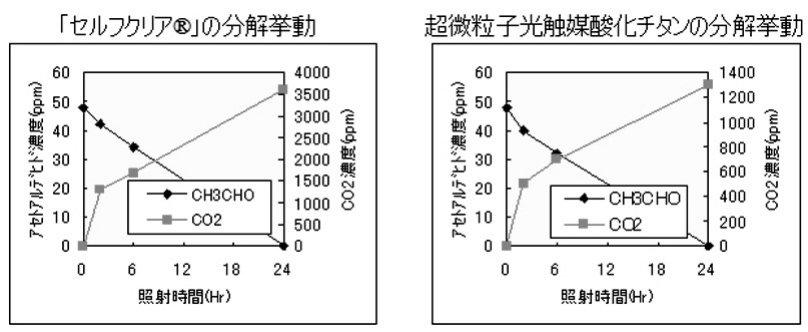

図 7 「セルフクリア ${ }^{\circledR} 」 の$ 分解挙動

\section{4 光触媒有効利用率}

次に「セルフクリア ${ }^{\circledR} 」 の$ 光触媒有効利用率を求めた。

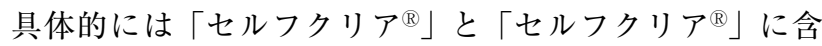
まれる超微粒子光触媒酸化于タン (超微粒子光触媒酸化于 タンの量は「セルフクリア ${ }^{\circledR} 」 の$ 含有量に合わせている) の各臭気成分に対する消臭速度から次式により算出した。

光触媒有効利用率 $=$

$\left\lceil セ ル フ ク リ ア{ }^{\circledR} 」\right.$ 消臭速度 - 空試験消臭速度

超微粒子光触媒酸化チタン消臭速度 - 空試験消臭速度

各臭気成分についての光触媒有効利用率を図 8 に示すが、 $\left\lceil セ ル フ ク リ ア{ }^{\circledR} 」 は\right.$ 様々な臭気成分に対し優れた光触媒 有効利用率を有している。尚、臭気成分により光触媒有効

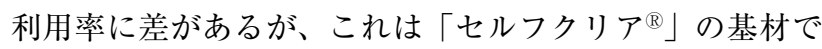
あるアクリル纎維に対する各臭気成分の化学的親和性が超 微粒子光触媒酸化チタンのそれと異なるためと思われる。

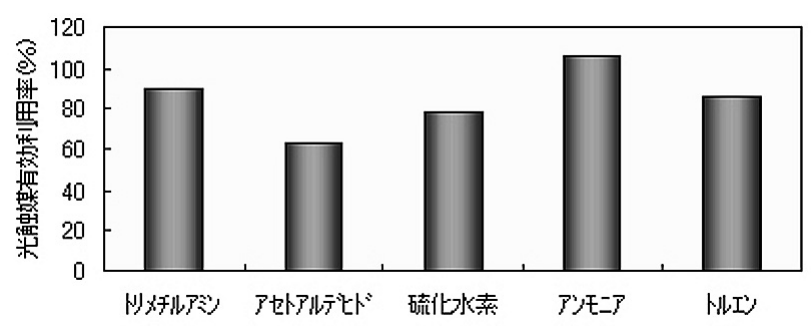

図 8 「セルフクリア ${ }^{\circledR} 」 の$ 光触媒有効利用率

\section{5 繰り返し消臭性能}

臭気成分アセトアルデヒドを用い、「セルフクリア ${ }^{\circledR} 」$ の繰り返し消臭性能を評価した。具体的には同一試料を用 い、(1) 臭気成分注入 $\Rightarrow(2)$ 紫外線照射 $\Rightarrow(3)$ 残留ガス濃度 測定 $\Rightarrow(4)$ 脱気、を 5 回繰り返した。その結果を図 9 に示 すが、「セルフクリア」 ${ }^{\circledR} 」$ 消臭性能は繰り返しにより低 


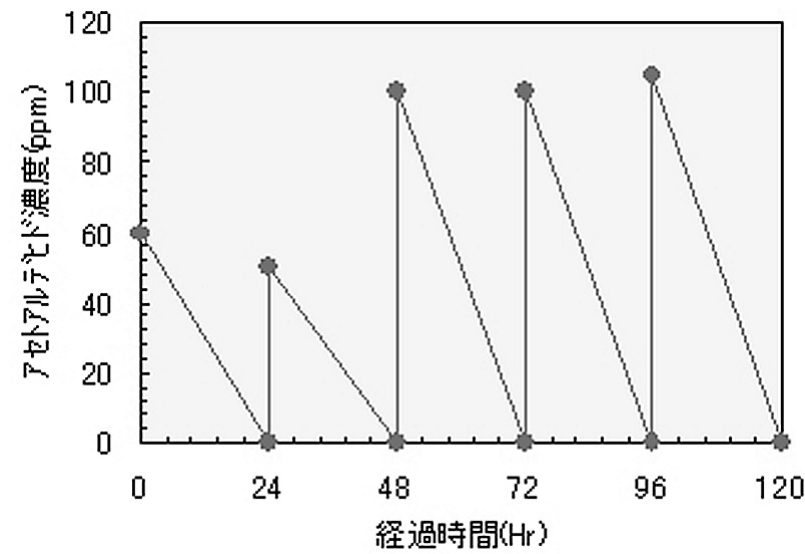

図 $9\left\lceil セ ル フ ク リ{ }^{\circledR} 」 の\right.$ 繰り返し消臭性能

下していないことが分かる。

\section{6「セルフクリ ${ }^{\circledR} 」$ の消臭性能}

$\lceil セ ル フ ク リ)^{\circledR} 」 の$ 各臭気成分に対する消臭性能を図 10 に示す。「セルフクリア ${ }^{\circledR} 」 は$ 代表的悪臭成分であるア セトアルデヒド、トリメチルアミン、硫化水素、酢酸、ア ンモニアのいずれに対しても優れた消臭性能を示すことが 分かる。

また、「セルフクリア ${ }^{\circledR} 」 は$ 従来物理吸着以外の化学的 方法では除去が困難であった BTX(ベンゼン、トルエン、 キシレン)についても図 11 に示すように良好な除去効果を 有し、繊維構造にナノサイズの表面連通細孔構造を導入し たことによる物理吸着と光触媒反応による相乗効果が発現 していることを示唆している。

\section{$3.7\left\lceil セ ル フ ク リ ア^{\circledR} 」 の\right.$ の污れ分解性能}

一般に光触媒材料は有害化学物質、悪臭、そして雑菌な どの有機物を分解することで、消臭、防污、浄化、抗菌な どの機能を発現すると考えられている9)。

衣類等に付着する污れの中でも、特に体から出る皮脂污 れは繊維内部にまで入り込み洗濯しても落ちないやっかい

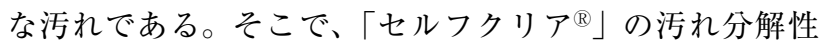
能を評価した。具体的には「セルフクリア ${ }^{\circledR} 」$ 編地と汎用 アクリル編地を準備し、卵 1 個/サラダ油 $0.1 \mathrm{~L} /$ 純水 $1 \mathrm{~L}$ の 混合液中に浸漬、脱水・乾燥し試料とした。各試料に紫外 線強度 $0.25 \mathrm{~mW} / \mathrm{cm}^{2}$ の光を所定時間照射し、その後、た んぱく質指示薬ニンヒドリン液を噴霧した。たんぱく質が

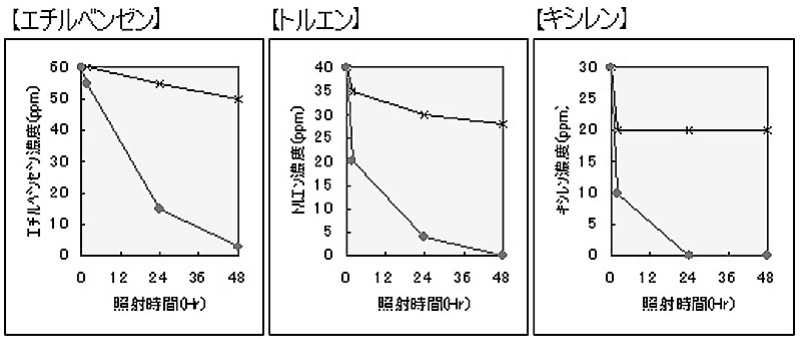

汶中記号 のセルつクリア」×沉用アクル

図11「セルフクリア ${ }^{\circledR} 」 の$ 消臭性能 $(2)$

残留しているとニンヒドリン液は紫色を呈する。評価結果 を図 12 に示すが、「セルフクリア ${ }^{\circledR} 」$ 編地は紫外線照射時 間の増加に伴いニンヒドリン呈色が薄くなっていることか ら皮脂污れ等の污れに対しても優れた分解性能を持つこと が分かる。

また、光触媒材料はじゅうぶんな光源があれば水質浄化 にも効果があると言われている。そこで、「セルフクリ $ア^{\circledR} 」$ の水中での污れ分解性能を評価した。具体的には「セ ルフクリア ${ }^{\circledR} 」$ 編地と汎用アクリル編地を準備し、濃度 $1 \mathrm{mg} / \mathrm{L}$ のメチレンブルー水溶液中に液面から $3 \mathrm{~cm}$ の深さ となるよう浸漬し、浸漬状態のままで水面の紫外線強度が $0.5 \mathrm{~mW} / \mathrm{cm}^{2}$ となるよう距離を調整した光を所定時間照射、 試料編地を取出し、脱水・乾燥した。評価結果を図 13 に 示すが、「セルフクリア ${ }^{\circledR} 」$ 編地を浸漬したメチレンブルー 水溶液は紫外線照射時間の増加に伴い水溶液は透明となり その結果として編地の着色も薄くなったことから水質浄化 に対しても効果を期待出来る。

\section{4. 応用}

このように多様な臭気成分に対し優れた消臭性能を示す

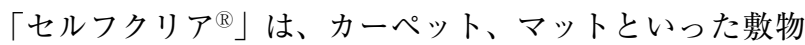
を中心に生活環境のさまざまなシーンでの活躍が期待され ている。

衣料：一般衣料、スポーツ衣料、ユニフォーム、その他衣 料品 (マフラー、手袋等)

インテリア：寝装品、ホームファッション

生活資材：スリッパ、布巾、タオル、テーブルクロス

資材その他：業務／家庭用フィルター、自動車内装品、医 療／介護用品、壁紙

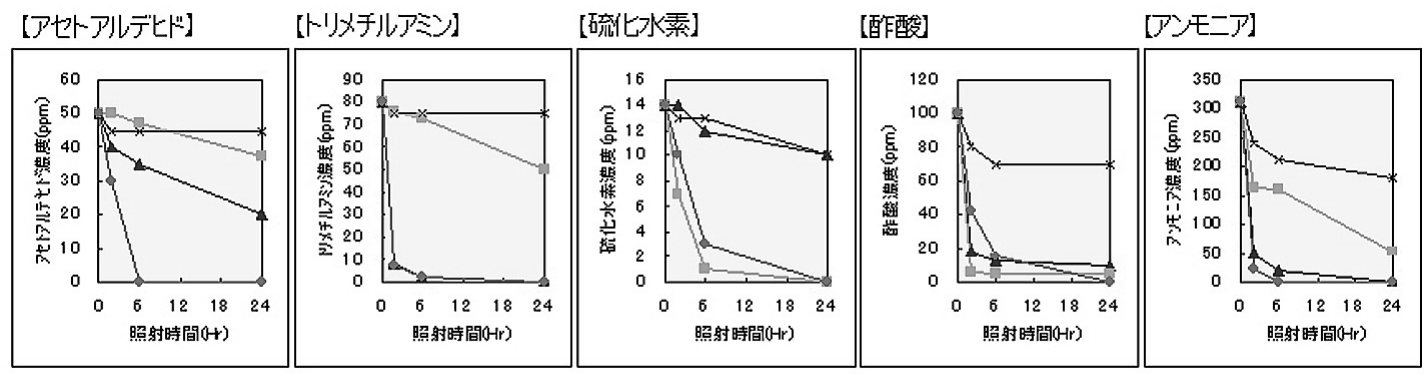

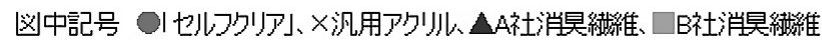

図10「セルフクリア ${ }^{\circledR} 」$ の消臭性能 (1) 

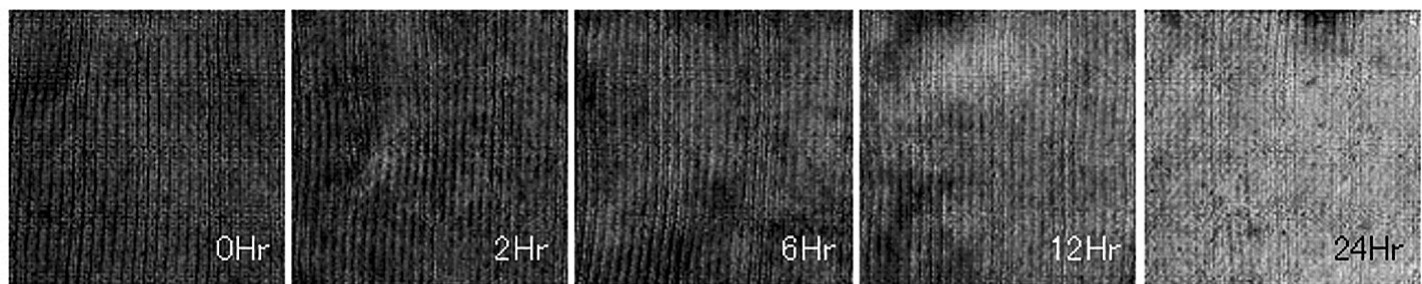

\section{けセルフクリア®編地}
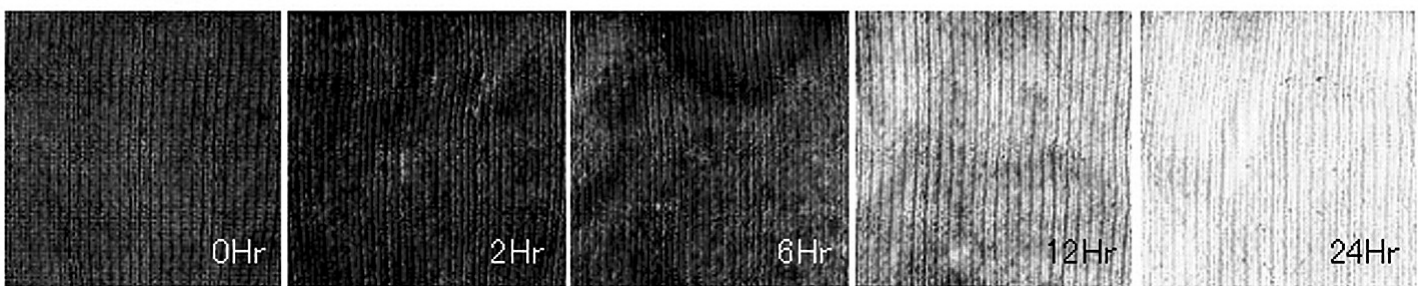

図12「セルフクリア ${ }^{\circledR} 」 の$ の污れ分解性能 $(1)$

\section{汎用アクリル編地}
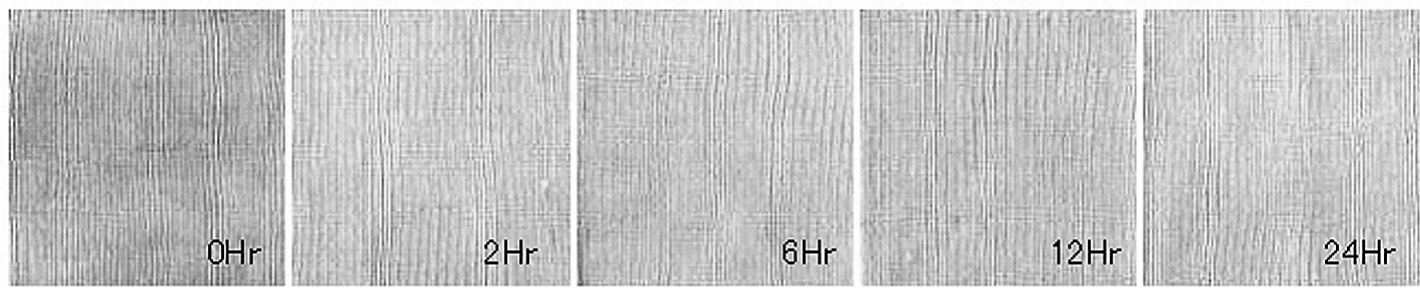

เセルつクリア®編地
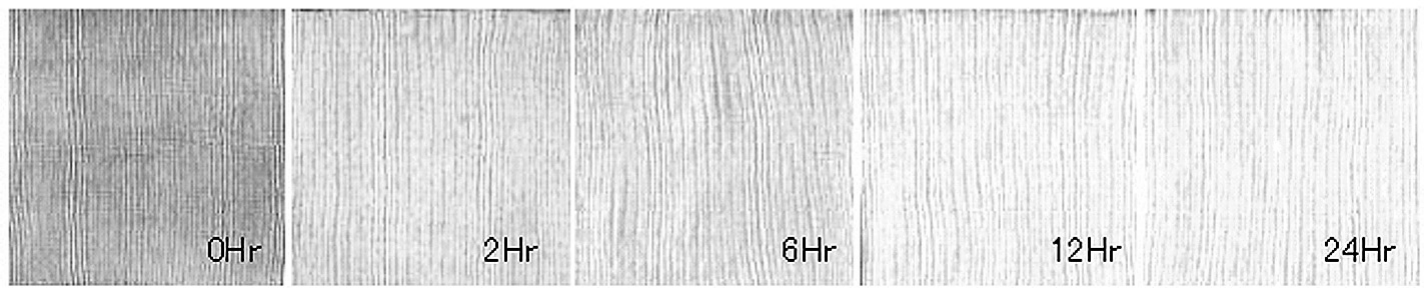

図13「セルフクリア ${ }^{\circledR} 」 の$ 污れ分解性能 (2)

\section{引用文献}

1)「瀻維の百科事典」

「芳香・消臭・脱臭剤の自主基準」、芳香消臭脱臭剤協 議会 (2003)、など

2）今西修三 ; 繊維製品消費科学、43(10)、632-642(2002).

3）木村睦；加工技術、38(4)、235-239(2003).

4）繊維評価技術協議会 ; 加工技術、38(4)、244-248、249251、252-256 (2003).
5）特許庁編；特許マップシリーズ「機能性瀻維加工」、 発明協会 (2000).

6）「光触媒 基礎 - 材料開発 - 応用」NTS 出版 (2005) など

7) Polymer handbook $4^{\text {th }}$ Edition, John Wiley \& Sons, Inc. (1999).

8）川上 博；瀻維学会誌、33(T-515)、(1977).

M. Fels ; J. Text. Inst., 51, 648(1960).

9）宮崎孝司；加工技術、37(2)、85-89(2002). 